УДК 621.396 .969

DOI: https://doi.org/10.26642/ten-2019-2(84)-120-125

Ж.М. Хоменко, к.т.н., ст. викл.

В.В. Ципоренко, доц., к.т.н.

І.М. Хоменко, асистент

В.Г. Ципоренко, доц., к.т.н.

Державний університет « Житомирська політехніка»

\title{
Система дистанційного моніторингу для визначення параметрів зворотно-поступального руху
}

\begin{abstract}
Особливість біорадіолокації полягає у тому, що спостережувані об'єкти, як правило, роблять не прямолінійний, а зворотно-поступальний рух (серие та грудна клітина людини). Одержання правильних результатів моніторингу ускладнюється ще й тим, щзо спостереження виконується на фоні відбиття радіолокачійного сигналу від об'єктів, щзо оточують спостережуваний об'єкт. У дійсності зондувальний сигнал відбивається не тільки від грудноі клітини людини та пацієнта, який обстежується в цілому, а й від нерухомих об'єктів, щчо знаходяться навколо, та вносить похибку в обчислення параметрів руху обстежуваного об'єкта. Якщзо радар використовується при наявності безлічі місиевих об'єктів, то в приймач потрапляють відбиття й від них. Оскільки сигнали, відбиті від декількох об'єктів, інтерферують, то положення цих об'єктів не ідентифікується. Наявність відбиттів від місиевих об'єктів (МО) призводить до появи у відбитому сигналі великої постійної складовоі (ПС), відрізнити яку від корисної ПС неможливо.
\end{abstract}

Таким чином, дистаниійне визначення параметрів серцебиття та дихання людини може бути вирішено за умови створення досить чутливого радіолокаційного датчика, розробки програмно-апаратного комплексу безконтактного радіолокаційного моніторингу параметрів руху біологічних структур та розроблення алгоритмів фільтрації фонових відбиттів, які можуть маскувати корисний сигнал. Наявність фонових відбиттів може бути пов'язана 3 реєстрацією сигналів, щзо відбиваються від оператора, або інших людей, які перебувають у зоні проведення вимірів. Все ие вимагає створення таких апаратних $i$ програмних засобів, які 6 забезпечили надійну, безпомилкову роботу біорадіолокачійного засобу навіть в умовах дії зовнішніх перешкод.

Поставлене завдання вирішується тим, щчо ділянка тіла дистанційно опромінюється електромагнітними хвилями надвисокої частоти фазовим локатором. Реєстрацію переміщень тканин ділянки тіла, зумовлених комбінованим впливом сериебиття та дихання, виконують за допомогою корисного сигналу, отриманого шляхом фільтрування низькочастотних складових, розкладанням сигналу на квадратурні складові та реєстраиї зміни фази сигналу.

Ключові слова: моніторинг; система контролю; інтермодуляція; зворотно-поступальний рух; радіолокаційний датчик; постійна складова (ПС); місиеві об'єкти (МО); ЕМП.

Вступ. Основною перевагою радіолокаційного зондування є здатність електромагнітних хвиль поширюватися в різноманітних діелектричних середовищах з високим ступенем неоднорідності й, крім того, можливе зондування «на відбиття» тобто коли приймач і передавач розташовані з однієї сторони досліджуваного об’єкта. Дослідження складних середовищ при однобічному підході і є основною областю застосування радіолокаційного зондування.

У даний час загострився інтерес до використання методів і засобів радіолокації діагностики життєвоважливих показників живих організмів. Це завдання може бути вирішене за допомогою радіолокаційних засобів, що працюють в частотному діапазоні 1-10 ГГц. У цьому випадку за рахунок віднімання сигналів, відбитих від нерухомих об’єктів, можна досягти високої чутливості при виявленні об'єктів, границі яких схильні до механічних коливань. При відбитті зондувального сигналу від рухомої границі, відбувається зміна фази сигналу, що може бути зафіксовано тим чи іншим способом.

Аналіз літературних даних та постановка проблеми. Дистанційна діагностика стану живих організмів може бути реалізована за допомогою радіолокаторів, що працюють на довжинах хвиль 3-30 см (1-10 ГГц). При цьому за рахунок віднімання сигналів, відбитих від нерухомих об'єктів, можна досягти високої чутливості при виявленні об'єктів, границі яких схильні до механічних коливань. При відбитті зондувального сигналу від рухомої границі відбувається зміна фази сигналу, що може бути зафіксовано тим чи іншим способом. Чутливість цього методу може досягати 10-9 м [1-3].

Механічні коливання об'єктів дослідження можуть бути вимушеними (викликані зовнішнім джерелом) або спонтанними (скорочення серцевих м’язів або дихальних рухів грудної клітини) [4]. Вихідний сигнал, відбитий від грудної клітини, являє собою суму високо-амплітудних хвиль, викликаних 
переміщеннями грудної клітини і діафрагми та низько-амплітудної складової, яка викликана переміщенням грудної стінки внаслідок серцевого поштовху [5].

При цьому зареєстрований сигнал є нестаціонарним і має значну внутрішньовидову варіабельність. У людини об'єктами, що піддаються періодичним коливанням, $\epsilon$ скорочення серцевого м'яза (частоти 0,8-2,5 Гц) і коливання грудної клітки в процесі дихання (частоти 0,2-0,5 Гц). Амплітуда складової серцевого ритму в зареєстрованому сигналі є невеликою та не перевищує 5 \% від амплітуди дихальної складової [6; 7].

Поставленим завданням є створення пристрою дистанційного моніторингу біоритмів обстежуваного об'єкта, що дозволить підвищити точність і вірогідність вимірів параметрів дихання та серцебиття пацієнтів за рахунок підвищення фазової чутливості діагностики обстежуваного об'єкта, виключення «сліпих» зон на всій робочій дистанції зондування, навіть при переміщенні обстежуваного пацієнта, а також підвищення точності відтворення функції руху та параметрів обстежуваного об'єкта, у тому числі з урахуванням відбитого сигналу від нерухомих об'єктів, що знаходяться поблизу обстежуваного об'єкта в зоні випромінювання зондувального сигналу.

Метою роботи $\epsilon$ розробка програмно-апаратного комплексу безконтактного радіолокаційного моніторингу параметрів руху біологічних структур для підвищення достовірності результатів синхронних досліджень дихання та серцебиття.

Для досягнення поставленої мети необхідно вирішити такі завдання:

- проаналізувати досвід застосування радіолокаторів технічного призначення для моніторингу дихання та серцебиття людини;

- розробити біотехнічну систему реєстрації параметрів дихання та серцебиття людини за допомогою радіолокатора.

Викладення основного матеріалу. Активний радіолокатор завжди містить передавальний i прийомний блоки. Завданням передавального блоку є випромінювання убік об'єкта, надвисоких частот (НВЧ) електромагнітної енергії, що виробляється генератором. Для цього до передавальної антени від генератора через металевий хвилевід підводиться модульований або немодульований НВЧ-сигнал. Немодульований сигнал є монохроматичним випромінюванням.

Завданням прийомного блоку є прийом відбитого від об'єкта сигналу та подальша його обробка 3 метою виділення корисної інформації про об’єкт. При цьому прийомний і передавальний блоки, як правило, поєднуються у загальний блок, що може мати роздільні передавальну та прийомну антени, а може мати загальну антену, що працює одночасно як на прийом, так і на передачу сигналу. В останньому випадку антена підключається до НВЧ-блоків через циркулятор. Завданням циркулятора є розведення по різних хвилевідних шляхах переданого сигналу від передавача та прийнятого сигналу, відбитого від об’єкта.

Пристрої, що входять до складу приймально-передаючого блоку, такі: генератор, спрямований відгалужувач, змішувач, дільник потужності, циркулятор, антена, фазозсувний пристрій, вентиль. Нижче наведені структурні схеми двох основних типів прийомо-передавачів неперервного випромінювання, що використовуються на практиці: гомодинного типу та супергетеродинного типу.

У гомодинній системі застосовується один генератор НВЧ-сигналу у прийомо-передавачі, у якому прийнятий НВЧ-сигнал переноситься на нульову частоту. Типова структурна схема гомодинного прийомопередавача наведена на рисунку 1. На виходах двох змішувачів у цій схемі маємо синусну та косинусну (квадратурні) складові сигналу, якщо об'єкт переміщується відносно антени прийомо-передавача.

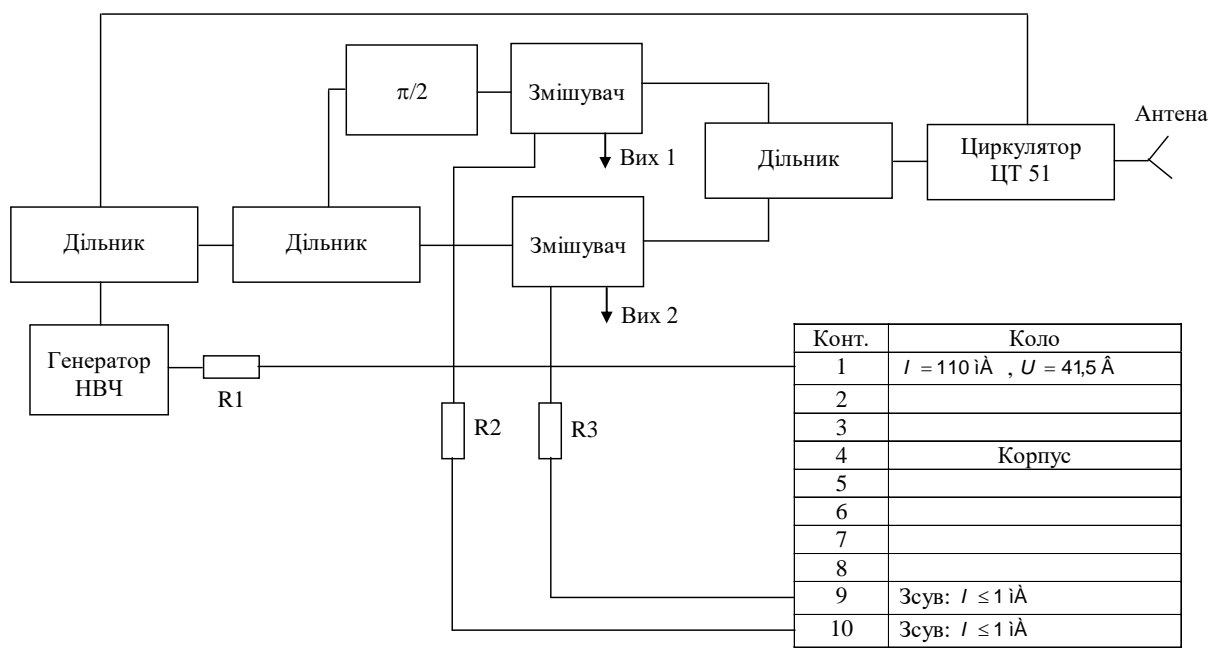

Рис. 1. Структурна схема гомодинного прийомо-передавача 
Основний ефект радіолокатора полягає в обробці вихідної напруги, що пропорційна швидкості переміщення об’єкта, що опромінюється, або у вимірі у часі відстані від випромінювача (антени) до об'єкта. При цьому фаза прийнятого прийомним пристроєм вимірювача сигналу лінійно залежить від відстані до об'єкта, а прийнята потужність сигналу має незначну нелінійну залежність від відстані. Дихання та серцебиття створюють невеликі переміщення поверхні тіла, у результаті чого відбита від об'єкта хвиля стає модульованою як за амплітудою, так і за фазою. Оскільки у міліметровому діапазоні хвиль крутість зміни фази набагато більша, ніж крутість зміни амплітуди у відбитому сигналі, доцільно будувати метод обробки сигналу на обробці фази відбитого сигналу. Виходячи 3 цього, при розробці вимірювача був обраний фазовий метод, що й визначив структурну схему із квадратурними каналами. Така структурна схема зображена на рисунку 2.

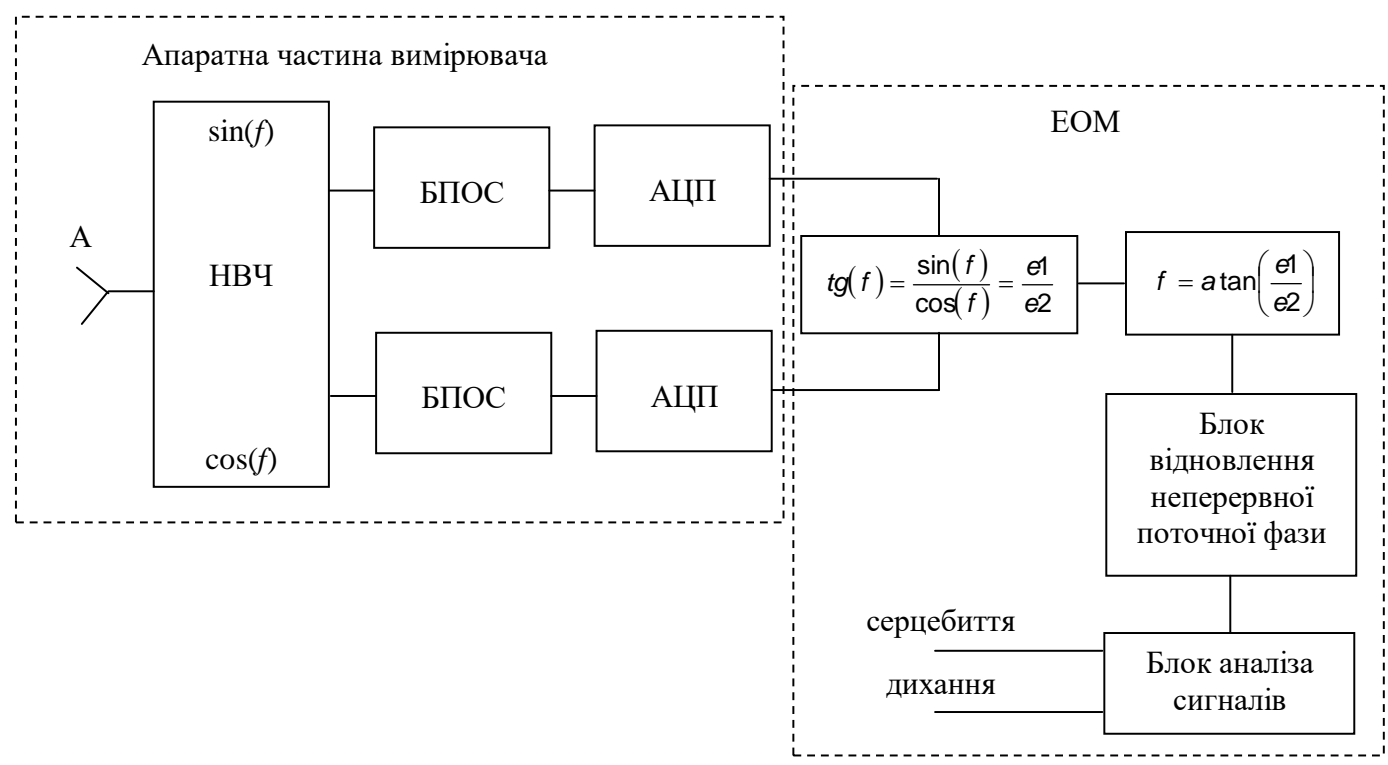

Рис. 2. Структурна схема з квадратурними каналами:

A - приймально-передавальна антена; НВЧ - блок обробки НВЧ сигналів; БПОС - блок попередньої обробки сигналів; АЦП - аналого-ичифровий перетворювач

Завданням НВЧ блоку є випромінювання, прийом і первинна обробка сигналу, відбитого від об’єкта, що рухається. Результат первинної обробки сигналу - це квадратурні компоненти відбитого сигналу, які після підсилення та дискретизації подаються на вхід персонального комп'ютера, у якому відбувається подальша обробка та аналіз відбитих від об’єкта сигналів за спеціально розробленими програмними алгоритмами.

У гомодинному пристрої на входи НВЧ-змішувачів приходять сигнали - один 3 несучою частотою, інший також з несучою частотою плюс або мінус зсув (рис. 1). Тому на виходах змішувачів з'являється напруга тільки частоти.

Для виділення фази відбитого від об'єкта сигналу, необхідно мати два квадратурних канали. Ці канали створюються за допомогою відгалуження від генератора частини потужності за допомогою рівноплечового дільника потужності та фазообертача перед змішувачем в одному з каналів, а на інші входи НВЧ-змішувачів подається сигнал, відбитий від об’єкта, який несе у собі інформацію про характер руху об'єкта, що міститься в прирості, до несучої частоти сигналу. На виході змішувачів зазначеної схеми маємо напруги із частотою, що перебувають у квадратурі, тобто мають зсув у $90^{\circ}$ відносно один одного, що забезпечується фазозсувною хвилевідною вставкою [10].

Гомодинні прийомо-передавачі, як правило, працюють на одну антену, що одночасно $\epsilon$ як передавальною, так i приймальною. Для розв'язки випромінюваного та прийнятого сигналів використовується циркулятор.

У схемі рисунка 1 призначенням баластового резистора R1 $є$ захист генератора від випадкових стрибків напруги живлення, а резистори R2 та R3 призначені для настроювання змішувачів на максимальний коефіцієнт перетворення.

Вимоги до передавальної частини системи.

У даний час визнано, що електромагнітне поле (ЕМП) впливає на людину. Численні дослідження в області біологічної дії ЕМП дозволяють визначити найбільш чутливі системи організму людини: нервова, імунна, ендокринна та статева. Ці системи організму є критичними з життєвих позицій. Реакції цих систем мають обов'язково враховуватися при оцінці ризику впливу ЕМП на населення. 
Сполучення перерахованих вище параметрів може давати істотно різні наслідки для реакції біологічного об'єкта, що опромінюється. На підставі сказаного вище можна зробити висновок, що опромінення електромагнітним полем $\epsilon$ специфічним як у плані механізмів реалізації біологічних ефектів, так й у плані накопичення та збільшення середнього рівня ЕМП у навколишньому середовищі, що пов'язано 3 неперервним ускладненням структури ЕМП. Отже, цей вид впливу принципово відрізняється від інших факторів фізичної та хімічної природи техногенного походження.

Гранично допустимі значення потужності при опроміненні біологічних об'єктів (у тому числі людини) мікрохвильовим випромінюванням, що є затвердженими ДСТУ, наведено в таблиці 1.

Гранично допустимі рівні опромінення НВЧ

Таблиияя 1

\begin{tabular}{|c|c|c|c|c|c|c|c|}
\hline ГДР, мкВт/см & \\
\hline Час роботи Т, ч & 8 & 7 & 5 & 4 & 28 & 200 & 1000 \\
\hline
\end{tabular}

Залежність щільності потоку енергії, що падає на об’єкт, розрахованого для випромінювання передавального генератора міліметрового діапазону та антени 3 діаграмою спрямованості, що має ширину $10^{\circ}$, наведено в таблиці 2 .

Розрахунок потужності, щзо падає на поверхню, щзо опромінюється,

Таблиия 2 при опромінюванні об 'єкта з відстані у 1 та 2 м

\begin{tabular}{|c|c|c|c|c|c|c|c|c|c|c|}
\hline $\begin{array}{c}\text { Потужність, що підводиться до } \\
\text { антени, мВт }\end{array}$ & 18 & 16 & 14 & 12 & 10 & 8 & 6 & 4 & 2 & 1 \\
\hline $\begin{array}{c}\text { Щільність потоку, мкВт/см², } \\
\text { енергії на відстані 1м }\end{array}$ & 75 & 67 & 58 & 50 & 42 & 33 & 25 & 17 & 8 & 4 \\
\hline $\begin{array}{c}\text { Щільність потоку, мкВт/см², } \\
\text { енергії на відстані } 2 \text { м }\end{array}$ & 19 & 17 & 13 & 12 & 10 & 8 & 6 & 4 & 2 & 1 \\
\hline
\end{tabular}

Виходячи зі значень, наведених у таблицях 1 та 2, можна визначити гранично допустимий рівень (ГДР) при професійних роботах для потужності антени, що дорівнює 5 мВт.

Для визначення величини мікропереміщень шкіряного покрову людини, пов'язаних із серцевим циклом та дихальним процесом, необхідно забезпечити рівномірне опромінення поверхні порядку $(0,1$ x 0,1) м² і щільність потоку потужності не більше 25 мкВт на см² (ДЕРЖСТАНДАРТ 12.1. 006-84) 3 міркувань безпеки пацієнта. При цьому ширина променя зондувального сигналу має становити близько $10^{\circ}$ за рівнем половинної потужності (0,5 Р).

Найпростішим пристроєм, що забезпечує зазначені вимоги, є конічна рупорна антена 3 діелектричною лінзою. Розміри такої антенної системи укладаються в габарити $3 \times 3$ см, а діаграма основного пелюстка має кутові розміри 8-10 при рівні бічних пелюстків $12-15$ дБ.

Вимоги до приймальної частини системи.

Архітектура приймача вибирається між гетеродинним i гомодинним. Гомодинний приймач перетворює сигнал руху у частоту. Фактори при виборі приймача для комплексного проектування включають вимоги до фільтрації, складності схеми, розміру та рівня шумів, так само як і компроміс між вартістю і якістю сигналу. Гомодинний приймач $є$ найпростішим за архітектурою та менш дорогим.

У свою чергу використання квадратурного приймача забезпечує поліпшення фазової демодуляції, але пов'язане зі збільшенням витрат на створення та енергоспоживання [9].

Неперервно-випромінюючий радар передає та приймає сигнал у дуже вузькій смузі пропускання. Чиста неперервно-випромінююча система може легко визначати цілі, що рухаються, за допомогою доплерівського зсуву отриманого сигналу.

Таким чином, застосування оригінальної схеми керування генератором НВЧ-сигналу дозволило істотно підвищити фазову чутливість діагностики досліджуваного об'єкта та виключити «сліпі» зони на всій робочій дистанції пристрою навіть при переміщенні обстежуваного пацієнта, що дозволило підвищити точність і вірогідність вимірів параметрів дихання та серцебиття.

Обговорення результатів досліджень.

Для перевірки достовірності результатів вимірів параметрів дихання та серцебиття був використаний біораділокатор (рис. 3), розроблений на кафедрі біомедичної інженерії та телекомунікацій ЖДТУ. 


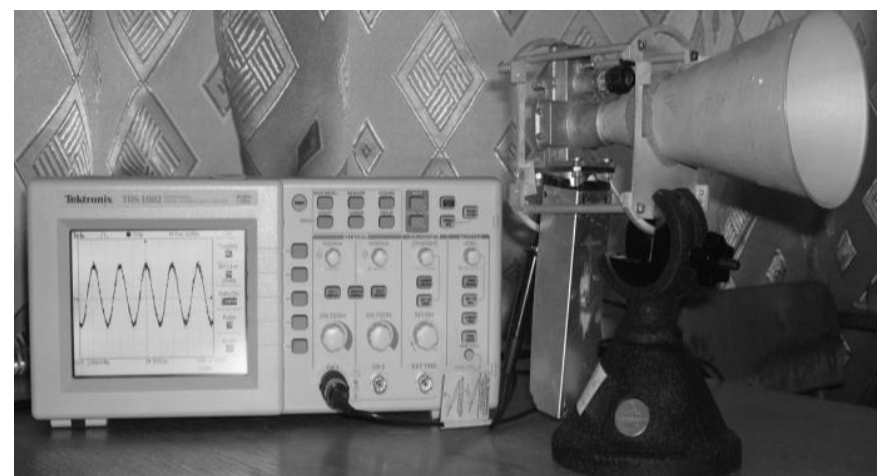

Рис. 3. Прилад дистаничійної реєстрайї сериеевої та дихальної діяльності

3 його допомогою було проведено порівняння даних оброблених на ПК з біорадіолокатора (рис. 4) та змодульованих сигналів в системі MatLab.

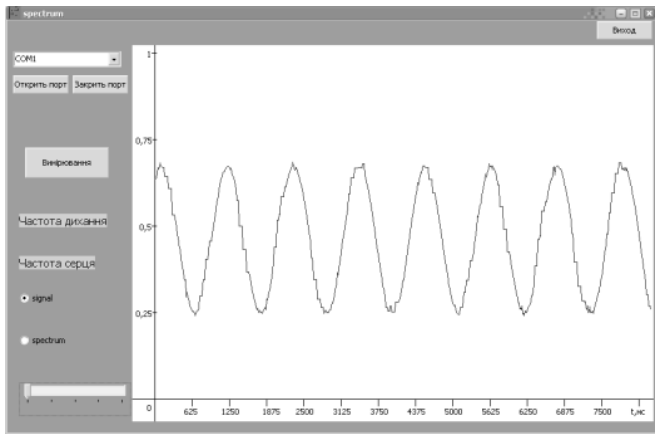

a)

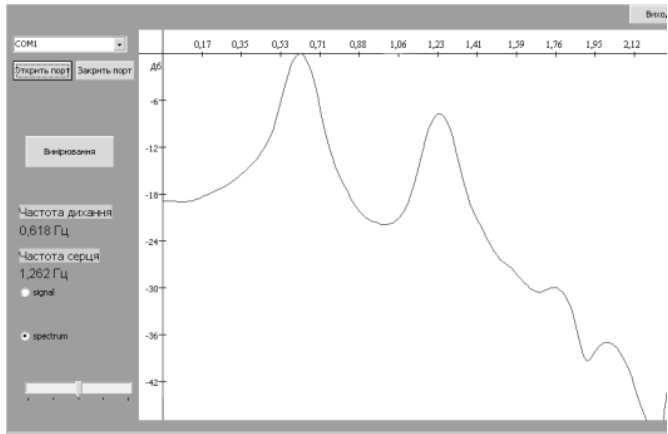

б)

Рис. 4. Порівняння сигналів: а) прийнятий сигнал, б) спектрограма

Для вимірювання інтервалів, використовуючи І-подібний курсор, в межах сегмента виділяється ділянка від початку циклу до його кінця та визначається частота й амплітуда. 3 наведеного прикладу можна зробити висновок про те, що розроблений програмний засіб дозволяє з великою вірогідністю відтворювати інформацію про серцеву діяльність людини, отриману дистанційним радіолокаційним методом [11].

Висновок. Було проведено аналіз сучасного стану методів моніторингу серцево-респіраторної активності людини, що підтвердило актуальність створення біомедичного засобу дистанційного моніторингу, також проведено аналітичне дослідження спектра фазової характеристики отриманого сигналу, що характеризує процес дихання та серцебиття людини. Частота дихання може бути легко оцінена на стадії стартової фільтрації сигналу. Проте рівень зсуву грудної клітини, викликаний диханням, на порядок вищий, ніж при серцебитті, тому при аналізі оцінка слабкого сигналу серцебиття, як у часовий, так й у частотній області ускладнена наявністю гармонік сигналу дихання та інтермодуляційних складових між диханням та серцебиттям. Оскільки частота дихання та ії інтенсивність може залежати від особистостей людини та ситуації, у деяких випадках частота першої гармоніки дихання та/або інтермодуляційні складові $\epsilon$ близькими до частоти серцебиття, що ускладнює визначення параметрів останнього. Для подолання цих проблем було запропоновано використання гармонійного компенсатора 3 попередньою смуговою фільтрацією складової серцебиття для автоматичного видалення гармонік сигналу дихання (а також для позбавлення від інтермодуляційних складових) [11].

Проведено експерименти по радіолокаційному зондуванню параметрів дихання та серцебиття дозволяють вважати задачу дистанційної діагностики стану людини розв’язною.

\section{Список використаної літератури:}

1. Bugaev A.S. Mathematical simulation of remote detection of human breathing and heartbeat by multifrequency radar on the background of local objects reflections / A.S. Bugaev, V.V. Chapursky, S.I. Ivashov // IEEE International Radar Conference, Arlington, Virginia, USA. - 2005. - P. 359-364.

2. Detection of human breathing and heartbeat by remote radar / S.I. Ivashov, V.V. Razevig, A.P. Sheyko, I.A. Vasilyev // Progress in Electro-magnetics Research Symposium (PIERS 2004), Pisa, Italy. - 2004. - P. 663-666.

3. Bugaev A.S. Through wall sensing of human breathing and heart beating by monochromatic radar / A.S. Bugaev, V.V. Chapursky, S.I. Ivashov // Proceedings of the Tenth International Conference on Ground Penetrating Radar (GPR'2004), Delft, The Netherlands. - 2004. - Vol. 1. - P. 291-294.

4. Biomedical technology and devises : handbook/ ed. by J.Moore, G.Zouridakis. - Boca Raton : CRC Press. - 2004. - 750 p.

5. Хоменко Ж.М. Методи визначення траєкторії руху цілі при побудові медичних радарів / Ж.М. Хоменко // Восточно-европейский журнал передовых технологий. - 2012. - № 6/11 (60). - С. 56-59. 
6. Береговая Н.В. Экспресс-анализ сердечно-сосудистой системы с помощью индуктивно-емкостной модели сердца / Н.В. Береговая, О.Л. Кореновская // 15-я Международная Крымская конференция «СВЧ-техника и телекоммуникационные технологии» (КрыМиКо 2005). Материалы конференции. - Севастополь : Вебер. - 2005. - T. 2. - С. 863-864.

7. Zito F. UWB 3.1-10.6 GHz CMOS transmitter for system-on-a-chip nano-power pulse radars / F.Zito, D.Zito, D.Pepe // Proceedings of the 3rd Conference on Ph.D. Research in Microelectronics and Electronics (PRIME '07). - Bordeaux, France. - 2007. - P. 189-192.

8. Федоров B.A. Радиотехнические методы в функциональной диагностике человека / В.A. Федоров. - М. : Изд. дом МЭИ, 2008. $-128 \mathrm{c.}$

9. Immoreev I. Practical application of ultra-wideband radars / I.Immoreev // Proceedings of ultrawideband and ultrashort impulse signals. - 2006. - P. 44-49.

10. Li C. Optimal carrier frequency of non-contact vital sign Detectors / C.Li, J.Lin // Proceedings of IEEE Radio and Wireless Symposium. - 2007. - P. 281-284.

11. Хоменко Ж.М. Дистанційна діагностика стану людини з використанням засобів цифрової обробки сигналів / Ж.М. Хоменко, С.М. Злепко, С.В. Тимчик // Міжнародний науково-технічний журнал «Вимірювальна та обчислювальна техніка в технологічних процесах». - 2012. - № 2. - С. 128-135.

\section{References:}

1. Bugaev, A.S., Chapursky, V.V. and Ivashov, S.I. (2005), «Mathematical simulation of remote detection of human breathing and heartbeat by multifrequency radar on the background of local objects reflections», IEEE International Radar Conference, Arlington, Virginia, USA, pp. 359-364.

2. Ivashov, S.I., Razevig, V.V., Sheyko, A.P. and Vasilyev, I.A. (2004), «Detection of human breathing and heartbeat by remote radar», Progress in Electro-magnetics Research Symposium (PIERS 2004), Pisa, Italy, pp. 663-666.

3. Bugaev, A.S., Chapursky, V.V. and Ivashov, S.I. (2004), «Through wall sensing of human breathing and heart beating by monochromatic radar», Proceedings of the Tenth International Conference on Ground Penetrating Radar (GPR'2004), Vol. 1, Delft, The Netherlands, pp. 291-294.

4. Moore, J. and Zouridakis, G. (ed.) (2004), Biomedical technology and devises, handbook, CRC Press, Raton, 750 p.

5. Homenko, Zh.M. (2012), «Metody vyznachennja trajektorii' ruhu cili pry pobudovi medychnyh radariv», Vostochno-evropejskyj zhurnal peredovblh tehnologyj, No. 6/11 (60), pp. 56-59.

6. Beregovaja, N.V. and Korenovskaja, O.L. (2005), «Jekspress-analiz serdechno-sosudistoj sistemy s pomoshh'ju induktivno-emkostnoj modeli serdca», 15-ja Mezhdunarodnaja Krymskaja konferencija «SVCh-tehnika $i$ telekommunikacionnye tehnologii (KryMiKo 2005), Materialy konferencii, Vol. 2, Veber, Sevastopol', pp. 863-864.

7. Zito, F., Zito, D. and Pepe, D. (2007), «UWB 3.1-10.6 GHz CMOS transmitter for system-on-a-chip nano-power pulse radars», Proceedings of the 3rd Conference on Ph.D. Research in Microelectronics and Electronics (PRIME '07), Bordeaux, France, pp. 189-192.

8. Fedorov, V.A. (2008), Radiotehnicheskie metody v funkcional'noj diagnostike cheloveka, Izd. dom MJeI, Moskva, 128 p.

9. Immoreev, I. (2006), «Practical application of ultra-wideband radars», Proceedings of ultrawideband and ultrashort impulse signals, pp. 44-49.

10. Li, C. and Lin, J. (2007), «Optimal carrier frequency of non-contact vital sign Detectors», Proceedings of IEEE Radio and Wireless Symposium, pp. 281-284.

11. Homenko, Zh.M., Zlepko, S.M. and Tymchyk, S.V. (2012), «Dystancijna diagnostyka stanu ljudyny z vykorystannjam zasobiv cyfrovoi' obrobky sygnaliv», Vymirjuval'na ta obchysljuval'na tehnika $v$ tehnologichnyh procesah, mizhnarodnyj naukovo-tehnichnyj zhurnal, No. 2, pp. 128-135.

Хоменко Жанна Миколаївна - кандидат технічних наук, старший викладач кафедри біомедичної інженерії та телекомунікацій Державного університету «Житомирська політехніка».

Наукові інтереси:

- біорадіолокація; математичні методи оптимізації; кінцеві пристрої абонентського доступу.

E-mail: joanekhomenko@gmail.com.

Ципоренко Віталій Валентинович - кандидат технічних наук, старший доцент кафедри біомедичної інженерії та телекомунікацій Державного університету «Житомирська політехніка».

Наукові інтереси:

- цифрові без пошукові методи кореляційно-інтерферометричного пеленгування.

Ципоренко Валентин Григорович - кандидат технічних наук, старший доцент кафедри Біомедичної інженерії та телекомунікацій Державного університету «Житомирська політехніка».

Наукові інтереси:

- цифрові спектрально-просторові методи виявлення та пеленгування радіосигналів.

Хоменко Інна Миколаївна - асистент, виконавець НДР № 51 Державного університету «Житомирська політехніка».

Наукові інтереси:

- радіолокація; цифрова фільтрація; пристрої підсилення. 